\title{
IMPLEMENTATION OF FUZZY LOGIC TO MEASURE THE PERFORMANCE OF THE TEACHER IN THE LEARNING PROCESS
}

\author{
Marry Agustina ${ }^{1}$, Vivi Sahfitri ${ }^{2}$
}

\begin{abstract}
The School is an institution that organizes education from Primary grades, Junior high and Senior high. In education, the school needs a teacher who became the most important component of which is the professional transfer of knowledge in order to take over the learning process to be able to produce the maximum Resources Human or graduates who have a high intellect in order to continue their education to a higher level. The performance is a concept tha is universal and operational effectiveness is an organization, a part of the organization and its employees based on the standards and criteria that have been set before. Teacher performance is a measure of the extent to which a teacher work optimally in accordance with its own capabilities in an effort to achieve the objectives of institutional. This study aims to measure the performance of the teacher in a junior high school in the implementation of the process of learning based on indicators of competence of teachers in the learning process by applying the method of Fuzzy Mamdani. Research results can be entered to improve teacher quality through the performance level they have and is one of the important factors in improving the quality of the school.
\end{abstract}

Keywords-Teacher, Teacher Performance, Mamdani Fuzzy

\section{Introduction}

Information technology is a form of development which resulted in many changes in various aspects of human life. The current use of technology and information is not something extraordinary, because the utilization of information technology is already a necessity in helping human activities. By utilizing information technology activities are quite difficult to do or activity that requires a lot of energy can be effective and efficient. One of the areas of life that are associated with the development of technology is in the education sector. In the field of education has been done the adoption of information technology to help the learning process in schools. An example is the use of e-learning in the learning process, the utilization of computer networks to interconnect via either the internet or the Intranet also utilization of various applications that can help a wide range of activities in education as well as its administrative system.

Teachers are an important part that can support the extent to which the quality of the schools. In the Arabic language, the teacher called the Mu'allim means someone that his job teaching to teach others. [1] The teacher is a professional transfer of knowledge at their disposal to participants of his protégé. More broadly the term teachers have a sense of someone who gave a science or his brilliance to a group or someone. The term teachers are not just for someone who taught the class for example Teacher reading the Quran, Karate Teacher, Piano teacher and others. Teachers as educators in schools certainly have a very large role and the quality of the teacher's role related to the performance of the teachers themselves.

The performance is a universal concept that operational effectiveness is an organization, part of organization, and its employees are based on standards and criteria that have been set previously. The performance is a human behaviour in the exercise of its role in an organization to meet the standards of behavior that has been established so that the resulted actions and desired results. The performance was seen as a result of the multiplication between abiliy and motivation. [2]

The performance was the work achievement, the execution of the work, the achievement of the work, the results of the work or performance. [3]. In conjunction with the world of education, then the performance ofthe teachers can be defined as the degree to which a teacher work optimally in accordance with its own capabilities in an effort to achieve the objectives of institutional. The ability of a teacher will look at the time teaching that can be measured from the competence to teach. The tasks and the role of teachers, among others, is to master the subject matter, and develop a plan and prepare daily lesson, control and evaluate the activities of student learning.[4]

Assessment of the performance of the teacher has several goals among other things, is to motivate teachers to maximize it works, improve performance on time or the next period and being a material consideration for the principal, trustees and the Office of education in providing the reward or punishment against the teacher. For tackling global problems the school need to apply a performance culture in the learning process. [5] .

In this research the used calculation method using Fuzzy logic. Fuzzy logic is a branch of artificial intelligence system that emulates human ability in thinking into the form of the algorithm will then be executed by the machine. This algorithm is used in a variety of applications processing data that cannot be represented in binary form. Fuzzy logic provides a way to describe a definitive conclusions from information that is vague, ambiguous and imprecise.

\section{Research Methodology}




\section{A. Research Methods}

The methods used in this research is descriptive method, is a method in researching the status of a group of humans, an object, a set of conditions, a system of thought, or an event in modern times. The purpose of this descriptive study was to make the description, picture or painting in a systematic, factual and accurate regarding the facts, properties and relationships between phenomena investigation.[6].

The data in this study were obtained through a method; a) Library Research, is a way of data collection undertaken by way of reading and studyingthe books, papers or other references that relate to issues that will be discussed, b) Observation, are a technique by way of organising observation and meticulous recording of systematically events, behavior, objects are seen and other things. [7], c) The interview, is the process of obtaining information for research purposes by way of questioning while face to face between the questioner or answerer with the respondent.[7].

\section{B. Fuzzy Logic}

Fuzzy Logic is the increase of the boolean logic introduces the concept of a partial truth. Where classical logic stating that everything can be expressed in terms of the binary ( 0 or 1 , black or white, yes or no), fuzzy logic replacing boolean truth with a level of truth. Fuzzy logic enables the membership values beetwen 0 and 1 , the level of possibilities and also black and white and ininthe form of a linguistic concept, not certainly like "little", "fair", and "very". Fuzzy logic and fuzzy sets related to probability theory.[8].

Fuzzy set has two attributes, namely:1) Linguistic, that is the name of a group that represent a specific form by using natural language, for example, Cold, cool, summer that represents a variable temperature. Other example such as: young, old representing the variable age, 2) Numerically, a value that indicates the size of a variable. For example: 10, 35, 40 and so on.[8].

Fuzzy method used in this researsh is a method of Mamdani fuzzy. Mamdani Fuzzy Method is often called bt the name of Max-Min Method. This Method was introduced by Ebrahim Mamdani in 1975. In Mamdani Fuzzy Methods there are 4 steps to get the output;

1) Establishment of fuzzy set, In Mamdani Method, either input or output variables are divided into one or more sets of Fuzzy.

2) Application Functionality Implications, In Mamdani Method the Application of function used the implication function Min (Minimum).

3) Rules of Composition, there are three methods used in conducting the fuzzy inference system ,namely: Max, additive and Probabilistic OR .

4) Affirmation (defuzzyfication), The Process of defuzzification can be seen in the picture below.

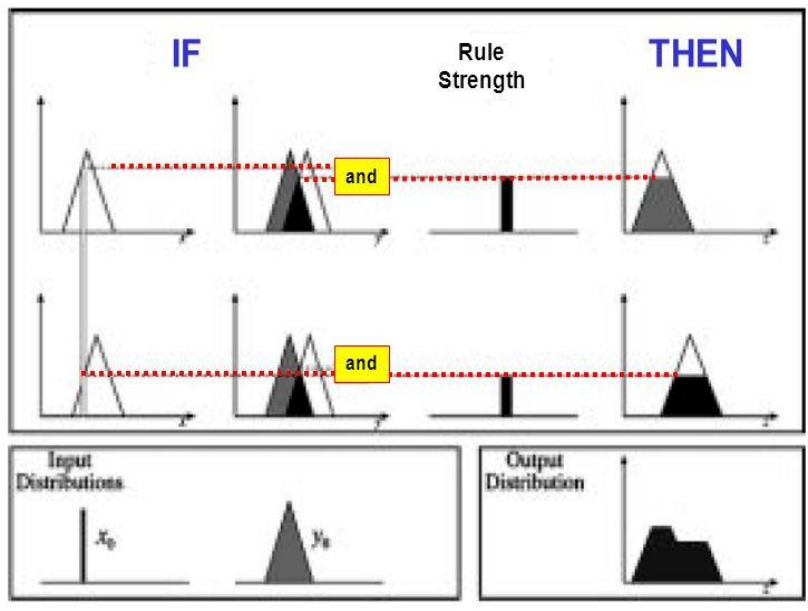

Figure 1. Defuzzification process

There are several methods of defuzzifikasi on the composition rules Mamdani Fuzzy methods, among other things;

a. The Centroid Method (Composite Moment)

In this method, a solution is obtained by taking a crisp center point $\left(\mathrm{z}^{*}\right)$ fuzzy area.

b. Bisector Methos

In tihis method, crisp solution obtained by taking values in the domain of fuzzy membership has of half of the value of membership in fuzzy areas.

c. Method of Mean of Maximum (MOM)

In this method, crisp solutions obtained by taking the average value of a domain that has a maximum membership values.

d. Largest Methos of Maximum (LOM)

In this method, crisp solutons obtained by taking the greatest value from a domain that has a maximum membership values.

e. Smallest method of Maximum (SOM)

In this method, crisp solutions obtained by taking the smallest value from a domain that has a maximum membership value.

\section{Result and Discussion}

\section{A. Requirement Analysis System of Teacher Performance Assessment.}

\section{- Input Data}

As data input for teacher performance assessment system is personal data or profile data and teacher performance appraisal of teachers for each variable performance assessment. For teacher performance variables consist of 8 variable that consists of: Craft, Speed, Productivity, Initiative, creativity, Cooperation, Dicipline, motivation and loyalty. 
Proc. of the Eighth International Conference On Advances in Computing, Electronics and Electrical Technology - CEET 2018 Copyright (C) Institute of Research Engineers and Doctors. All rights reserved.

ISBN: 978-1-63248-144-3 doi: 10.15224/ 978-1-63248-144-3-28

\section{- The Logic of the Process}

Based on the assessment of the performance of each teacher conducted by part of the academic curriculum in high school, furthermore the data will be processed based on fuzzy logic namely; Fuzzification, application Functionality Implications, Composition Rules and defuzzification.

\section{- The Information Generate}

As a result of the process off applying the method of fuzy is the value of the performance of the teacher in the learning process of one academic year.

\section{в. Implementation of Fuzzy Method}

In Mamdani method, either input or output variables are divide in to one or more sets of fuzzy. In this case the researcher determine the first hosts speaker of a variables that has been set. The Universe of the speaker set can be seen in table1.

TABLE 1. FUZZY VARIABLES

\begin{tabular}{|l|l|c|}
\hline Function Name & \multicolumn{1}{|c|}{ Variable } & Host a Speakers \\
\hline \multirow{4}{*}{ Input } & Craft & {$[1-20]$} \\
\cline { 2 - 3 } & Speed & {$[1-15]$} \\
\cline { 2 - 3 } & Productivity & {$[1-10]$} \\
\cline { 2 - 3 } & Initiative & {$[1-10]$} \\
\cline { 2 - 3 } & Cooperation & {$[1-10]$} \\
\cline { 2 - 3 } & Dicipline & {$[1-10]$} \\
\cline { 2 - 3 } & Motivation & {$[1-10]$} \\
\cline { 2 - 3 } & Loyalty & {$[1-15]$} \\
\hline Ouput & Performance of Teacher & {$[1-100]$} \\
\hline
\end{tabular}

After determining the hosts speaker at next determines the set of variables, fuzzy variable for input and output. The set of variable fuzzy on input can be seen in table 2 .

TABLE 2. THE SET OF FUZZY VARIABLE INPUT

\begin{tabular}{|c|c|c|}
\hline Variable & Set & Domain \\
\hline \multirow[t]{3}{*}{ Craft } & Low & {$[1-10]$} \\
\hline & Average & {$[5-15]$} \\
\hline & High & {$[10-20]$} \\
\hline \multirow[t]{3}{*}{ Speed } & Low & {$[1-8]$} \\
\hline & Average & {$[4-12]$} \\
\hline & High & {$[8-15]$} \\
\hline \multirow[t]{3}{*}{ Productivity } & Low & {$[1-5]$} \\
\hline & Average & {$[3-7]$} \\
\hline & High & {$[5-10]$} \\
\hline \multirow[t]{3}{*}{ Initiative } & Low & {$[1-5]$} \\
\hline & Average & {$[3-7]$} \\
\hline & High & {$[5-10]$} \\
\hline \multirow[t]{3}{*}{ Cooperation } & Low & {$[1-5]$} \\
\hline & Average & {$[3-7]$} \\
\hline & High & {$[5-10]$} \\
\hline \multirow[t]{3}{*}{ Dicipline } & Low & {$[1-5]$} \\
\hline & Average & {$[3-7]$} \\
\hline & High & {$[5-10]$} \\
\hline \multirow[t]{3}{*}{ Motivation } & Low & {$[1-5]$} \\
\hline & Average & {$[3-7]$} \\
\hline & High & {$[5-10]$} \\
\hline \multirow[t]{3}{*}{ Loyalti } & Low & {$[1-8]$} \\
\hline & Average & {$[4-12]$} \\
\hline & High & {$[8-15]$} \\
\hline
\end{tabular}

Fuzzy set in the variable output can be seen in table 3 .
TABLE 3. OUTPUT VARIABLE FUZZY SET

\begin{tabular}{|l|l|c|}
\hline \multicolumn{1}{|c|}{ Variables } & \multicolumn{1}{|c|}{ Set } & Domain \\
\hline Teacher Performance & Less & {$[0-45]$} \\
\cline { 2 - 3 } & Enough & {$[46-55]$} \\
\cline { 2 - 3 } & Good & {$[56-75]$} \\
\cline { 2 - 3 } & Very Good & {$[76-100]$} \\
\hline
\end{tabular}

Table 4 displays the performance appraisal data 3 teachers.

TABLE 4. PERFORMANCE ASSESSMENT DATA 3 TEACHERS

\begin{tabular}{|l|c|c|c|}
\hline Variable & Mr. Nanang & Mr. Fajri & Mrs. Nurul \\
\hline Craft & 18 & 12 & 4 \\
\hline Speed & 13 & 7 & 3 \\
\hline Productivity & 9 & 8 & 6 \\
\hline Initiative & 4 & 2 & 8 \\
\hline Cooperation & 8 & 9 & 8 \\
\hline Dicipline & 9 & 6 & 2 \\
\hline Motivation & 7 & 5 & 7 \\
\hline Loyalty & 11 & 14 & 11 \\
\hline
\end{tabular}

From these data the first step in determining the membership function in advance of each variable as follows: 1) Craft

To craft variable used 3 kinds of curves, namely: a linier curve, Linier ride down and the triangle curve. Description of curve of the craft can be seen in figure 2 .

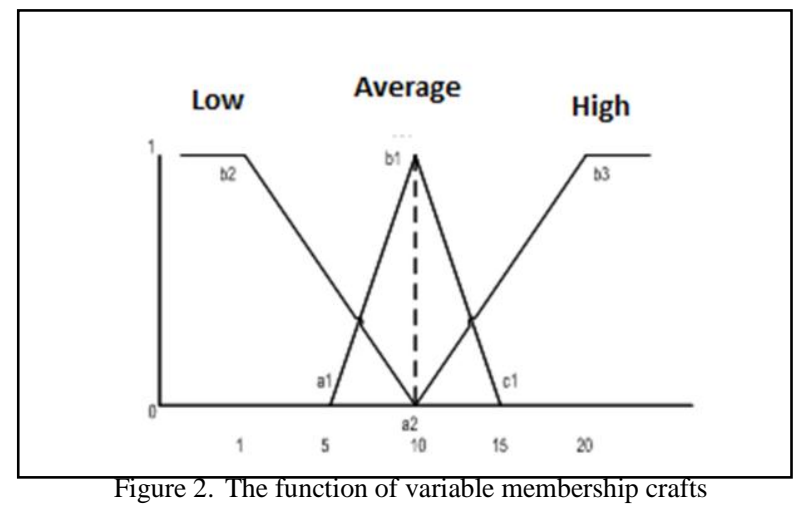

The result of the calculation of the variable on Respondent to Craft Variable can be seen in table 5 .

TABLE 5. Respondent Calculation Result For Craft Variable

\begin{tabular}{|c|c|c|c|c|}
\hline \multirow[t]{2}{*}{ Respondent } & \multicolumn{3}{|c|}{ Type of Curve } & \multirow{2}{*}{$\begin{array}{l}\text { Set } \\
\text { Variable }\end{array}$} \\
\hline & $\begin{array}{c}\text { Linier } \\
\text { Curve Rises }\end{array}$ & $\begin{array}{l}\text { Linier } \\
\text { Curve } \\
\text { Down }\end{array}$ & $\begin{array}{c}\text { Triangle } \\
\text { Curve }\end{array}$ & \\
\hline Mr. Nanang & 0,8 & - & - & High \\
\hline Mr. Fajri & 0,2 & 0,6 & - & $\begin{array}{c}\text { Average } \\
\text { High }\end{array}$ \\
\hline Mrs. Nurul & - & - & 0,66 & Low \\
\hline
\end{tabular}

\section{2) Speed, Productivity and Loyalty}

For variable speed, Productivity and loyalty using 3 kinds of curve namely. a linear curve, linear ride down and the triangle. Description of curve of speed and loyalty can be seen on the picture of the membership function of the speed and loyalty can be seen in Figure 3. 
Proc. of the Eighth International Conference On Advances in Computing, Electronics and Electrical Technology - CEET 2018 Copyright (C Institute of Research Engineers and Doctors. All rights reserved.

ISBN: 978-1-63248-144-3 doi: 10.15224/ 978-1-63248-144-3-28

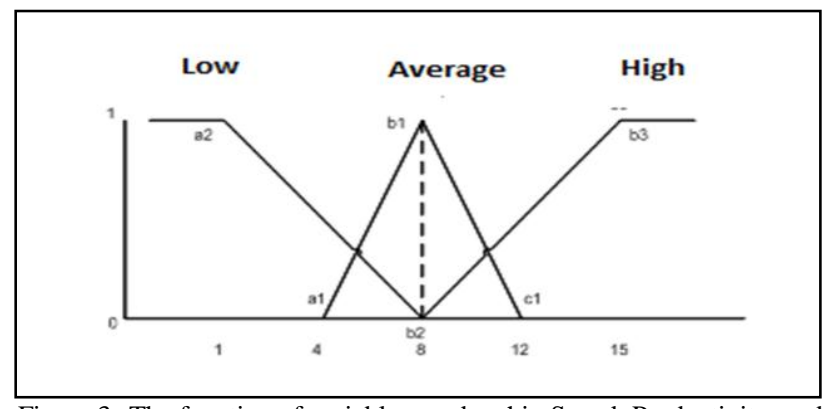

Figure 3. The function of variable membership Speed, Productivity and Loyalty

The result of the calculation of the variable on Respondent to speed, Productivity and Loyalty Variable can be seen in table 6,7 and table 8 .

TABLE 6. Respondent Calculation Result For Speed Variable

\begin{tabular}{|c|c|c|c|c|}
\hline \multirow[t]{2}{*}{ Respondent } & \multicolumn{3}{|c|}{ Type of Curve } & \multirow{2}{*}{$\begin{array}{l}\text { Set } \\
\text { Variable }\end{array}$} \\
\hline & $\begin{array}{c}\text { Linier } \\
\text { Curve Rises }\end{array}$ & $\begin{array}{c}\text { Linier Curve } \\
\text { Down }\end{array}$ & $\begin{array}{c}\text { Triangle } \\
\text { Curve }\end{array}$ & \\
\hline Mr. Nanang & 0,714 & - & - & High \\
\hline Mr. Fajri & 0,75 & - & 0,14 & $\begin{array}{c}\text { Average } \\
\text { Low }\end{array}$ \\
\hline Mrs. Nurul & - & 0,714 & - & Low \\
\hline
\end{tabular}

TABLE 7. Respondent Calculation Result For Productivity Variable

\begin{tabular}{|c|c|c|c|c|}
\hline \multirow[t]{2}{*}{ Respondent } & \multicolumn{3}{|c|}{ Type of Curve } & \multirow{2}{*}{$\begin{array}{l}\text { Set } \\
\text { Variable }\end{array}$} \\
\hline & $\begin{array}{c}\text { Linier } \\
\text { Curve Rises }\end{array}$ & $\begin{array}{c}\text { Linier Curve } \\
\text { Down }\end{array}$ & $\begin{array}{c}\text { Triangle } \\
\text { Curve }\end{array}$ & \\
\hline Mr. Nanang & 0,8 & - & - & High \\
\hline Mr. Fajri & 0,6 & - & 0,14 & High \\
\hline Mrs. Nurul & 0,2 & - & 0,5 & Low \\
\hline
\end{tabular}

TABLE 8. Respondent Calculation Result For Loyalty Variable

\begin{tabular}{|c|c|c|c|c|}
\hline \multirow[t]{2}{*}{ Respondent } & \multicolumn{3}{|c|}{ Type of Curve } & \multirow{2}{*}{$\begin{array}{l}\text { Set } \\
\text { Variable }\end{array}$} \\
\hline & $\begin{array}{c}\text { Linier } \\
\text { Curve Rises }\end{array}$ & $\begin{array}{c}\text { Linier Curve } \\
\text { Down }\end{array}$ & $\begin{array}{c}\text { Triangle } \\
\text { Curve }\end{array}$ & \\
\hline Mr. Nanang & 0,248 & - & 0,25 & $\begin{array}{c}\text { High } \\
\text { Average }\end{array}$ \\
\hline Mr. Fajri & 0,85 & - & - & High Set \\
\hline Mrs. Nurul & 0,428 & - & - & $\begin{array}{c}\text { Average } \\
\text { high }\end{array}$ \\
\hline
\end{tabular}

3) Initiative, Cooperation, Dicipline and Motivation

For variable Initiative, Cooperation, Dicipline and Motivation using 3 kinds of curve namely;. a linear curve, linear ride down and the triangle. Description of curve of Initiative, Cooperation, Dicipline and Motivation can be seen on the picture of the membership function of the speed and loyalty can be seen in Figure 4.

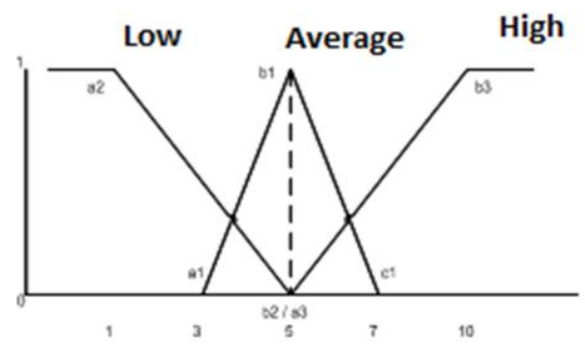

Figure 3. The function of variable membership Initiative, Cooperation, dicipline and Motivation
The result of the calculation of the variable on Respondent to Initiative, Cooperation, Dicipline and Motivation Variable can be seen in table $9,10,11$ and table 12 .

TABLE 9. Respondent Calculation Result For Initiative Variable

\begin{tabular}{|l|c|c|c|c|}
\hline \multirow{2}{*}{ Respondent } & \multicolumn{3}{|c|}{ Type of Curve } & $\begin{array}{l}\text { Set } \\
\text { Variable }\end{array}$ \\
\cline { 2 - 4 } & $\begin{array}{c}\text { Linier } \\
\text { Curve Rises }\end{array}$ & $\begin{array}{c}\text { Linier Curve } \\
\text { Down }\end{array}$ & $\begin{array}{c}\text { Triangle } \\
\text { Curve }\end{array}$ & \\
\hline Mr. Nanang & - & 0,25 & - & Low \\
\hline Mr. Fajri & - & 0,75 & 0,14 & Low \\
\hline Mrs. Nurul & 0,6 & - & - & High \\
\hline
\end{tabular}

TABLE 10. Respondent Calculation Result For CoopeartionVariable

\begin{tabular}{|l|c|c|c|c|}
\hline \multirow{2}{*}{ Respondent } & \multicolumn{3}{|c|}{ Type of Curve } & $\begin{array}{l}\text { Set } \\
\text { Variable }\end{array}$ \\
\cline { 2 - 4 } & $\begin{array}{c}\text { Linier } \\
\text { Curve Rises }\end{array}$ & $\begin{array}{c}\text { Linier Curve } \\
\text { Down }\end{array}$ & $\begin{array}{c}\text { Triangle } \\
\text { Curve }\end{array}$ & \\
\hline Mr. Nanang & 0,6 & - & - & High \\
\hline Mr. Fajri & 0,8 & - & - & High \\
\hline Mrs. Nurul & 0,6 & - & - & High \\
\hline
\end{tabular}

TABLE 11. Respondent Calculation Result For Dicipline Variable

\begin{tabular}{|c|c|c|c|c|}
\hline \multirow[t]{2}{*}{ Respondent } & \multicolumn{3}{|c|}{ Type of Curve } & \multirow{2}{*}{$\begin{array}{l}\text { Set } \\
\text { Variable }\end{array}$} \\
\hline & $\begin{array}{c}\text { Linier } \\
\text { Curve Rises }\end{array}$ & $\begin{array}{c}\text { Linier Curve } \\
\text { Down }\end{array}$ & $\begin{array}{c}\text { Triangle } \\
\text { Curve }\end{array}$ & \\
\hline Mr. Nanang & 0,8 & - & - & High \\
\hline Mr. Fajri & 0,8 & - & 0,2 & $\begin{array}{c}\text { Average } \\
\text { High }\end{array}$ \\
\hline Mrs. Nurul & - & - & 0,75 & Low \\
\hline
\end{tabular}

TABLE 12. Respondent Calculation Result For Motivation Variable

\begin{tabular}{|c|c|c|c|c|}
\hline \multirow[t]{2}{*}{ Respondent } & \multicolumn{3}{|c|}{ Type of Curve } & \multirow{2}{*}{$\begin{array}{l}\text { Set } \\
\text { Variable }\end{array}$} \\
\hline & $\begin{array}{c}\text { Linier } \\
\text { Curve Rises }\end{array}$ & $\begin{array}{c}\text { Linier Curve } \\
\text { Down }\end{array}$ & $\begin{array}{c}\text { Triangle } \\
\text { Curve }\end{array}$ & \\
\hline Mr. Nanang & 0,4 & - & 0,4 & $\begin{array}{c}\text { Average } \\
\text { High }\end{array}$ \\
\hline Mr. Fajri & 0,75 & 0 & 1 & $\begin{array}{c}\text { Average } \\
\text { Low }\end{array}$ \\
\hline Mrs. Nurul & 0,4 & - & 0 & $\begin{array}{c}\text { Average } \\
\text { High }\end{array}$ \\
\hline
\end{tabular}

\section{Implications of Application Functionality}

In mamdani's method applications function used is the implication function Min. This stage is penetuan the rules of the system logika fuzzy, the rules could be established to determine the relationship between input and output. The operator that is used to connect the input rules describing the And operator is between the inputoutput is IF - THEN. In this case the implications are;

1) Mr. Nanang :

[RI] = IF Craft is High (0.8) and Speed is High (0.714) and Productivity is High (0.8) and Initiative is Low (0.25) and Coopeartion is High (0.6) and dicipline is High (0.8) and motivation is High (0.4) and loyalty is average (0.25) THEN output is Good

$=\min (0.8 ; 0.714 ; 0.8 ; 0.25 ; 0.6 ; 0.8 ; 0.4 ; 0.25)$

$=0.25$

[R2] = IF Craft is High(0.8) and Speed is High (0.714) and Productivity is High (0.8) and initiative is average (0.5) and cooperation is High (0.6) and dicipline is high (0.8) and motivation is high (0.4) and loyalty is high (0.42) THEN output isvery Good

$=\min (0.8 ; 0.714 ; 0.8 ; 0.5 ; 0.6 ; 0.8 ; 0.4 ; 0.42)$

$=0.4$ 


\section{2) Mr. Fajri :}

$[\mathrm{R} 1]=I F$ craft is average (0.6) and speed is low (0.14) and productivity is high (0.6) and initiative is low (0.75) and coopeartion is high (0.8) and dicipline is average (0.5) and motivation is average (1) and loyalty is high (0.85) THEN output is good

$=\min (0.6 ; 0.14 ; 0.6 ; 0.75 ; 0.8 ; 0.5 ; 1 ; 0.85)$

$=0.5$

[R2] = IF Craft is high (0.2) and speed is average(0.75) and productivity is high (0.6) and initiative is low (0.75) and cooperation is high (0.8) and dicipline is average (0.5) and motivation is average (0) and loyallty is high (0.85) THEN output is good

$=\min (0.2 ; 0.14 ; 0.6 ; 0.75 ; 0.8 ; 0.5 ; 0 ; 0.85)$

$=0$

3) Mrs. Nurul :

$[\mathrm{R} 1]=$ IF craft is low (0.66) and speed is low(0.714) and productivity is average (0.5) andinitiative is high (0.6) and cooperation is high (0.6) and dicipline is low (0.75) and motivation is high (0.4) and loyalty is high (0.428) THEN output isgood

$=\min 0.66 ; 0.714 ; 0.5 ; 0.6 ; 0.6 ; 0.75 ; 0.4 ; 0.428)$

$=0.4$

$[\mathrm{R} 2]=I F$ craft is low(0.66) and speed is low (0.714) and produvtivity is low (0.2) and initiative is low (0.6) and cooperation is low(0.6) and dicipline is low (0.75) and motivation is high (0.4) and loyalty is average (0.25) THEN output is good

$=\min (0.66 ; 0.714 ; 0.2 ; 0.6 ; 0.6 ; 0.75 ; 0.4 ; 0.25)$

$=0.2$

\section{Rules Composition}

The composition of the rules used in fuzzy systems, namely the method of MAX.

\section{1) Mr. Nanang :}

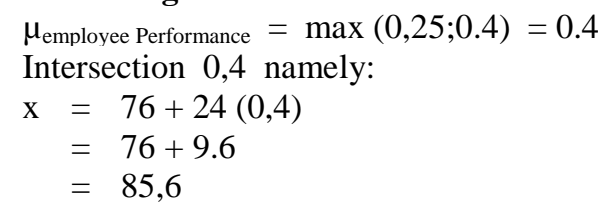

Membership function solution area:

$\mu_{\text {employee Performance }}=\{0.4,85.6 \leq \mathrm{x} \leq 100\}$

2) Mr. Fajri :

$\mu_{\text {employee Performance }}=\max (0.5 ; 0)=0.5$

Intersection 0,5 namely:

$$
\begin{aligned}
\mathrm{x} & =56+19(0.5) \\
& =56+9.5 \\
& =65.6
\end{aligned}
$$

Membership function solution area:

$\mu_{\text {employee Performance }}=\{0.5,65.5 \leq \mathrm{x} \leq 75\}$

\section{3) Mrs. Nurul :}

$\mu_{\text {employee Performance }}=\max (0.2 ; 0.4)=0.4$

Intersection 0, 4 namely:

$\mathrm{x}=56+19(0.4)$

$$
=56+7.6=63.6
$$

Membership function solution area:

$\mu_{\text {employee Performance }}=\{0.5,63.6 \leq \mathrm{x} \leq 75\}$

\section{E. Defuzzification}

The input of the process defuzzification is a fuzzy set is obtained from the composition of the fuzzy rules, while the generated output is some number on a set of fuzzy domain. The last stage, namely deffuzification, in this stage the methods used namely centroid method.

1) Mr. Nanang

$$
\begin{array}{r}
X=\frac{\int_{85.6}^{100}(0.4) x d x}{\int_{85.6}^{100}(0.4) d x} \\
=\frac{0.2 x^{2} \mid \frac{100}{85.6}}{0.4 x \mid \frac{100}{85.6}} \\
=\frac{2000-1465.472}{40-34.24}=\frac{534.528}{5.76}=92.8
\end{array}
$$

The Value og Employee Performance 92,8, it contains the category very good

2) Mr. Fajri

$$
\begin{array}{r}
X=\frac{\int_{65.5}^{75}(0.5) x d x}{\int_{65.5}^{75}(0.5) d x} \\
=\frac{0.25 x^{2} \mid \frac{75}{65.5}}{0.5 x \mid \frac{75}{65.5}} \\
=\frac{1406.25-1072.5625}{37.5-32.75}=\frac{333.6875}{4.75}=70.25
\end{array}
$$

The Value og Employee Performance 70,2, it contains the category Good

3) Mrs. Nurul

$$
\begin{gathered}
=\frac{\int_{63.6}^{75}(0.4) x d x}{\int_{63.6}^{75}(0.4) d x} \\
=\frac{0.2 x^{2} \mid \frac{75}{63.6}}{0.4 x \mid \frac{75}{63.6}} \\
=\frac{1125-808.992}{30-25.44}=\frac{316.008}{4.56}=69.3
\end{gathered}
$$

The Value og Employee Performance 69,3, it contains the category Good

\section{Conclusion}

Based on the discussion provided it can be concluded from the implementation method of fuzzy systems mamdani to teacher performance assessment are follows;

1. The calculation of the value of teacher performance that producedan accomplished teachers use the stages or steps of the same process and clear. 
2. The value of the performance of each teacher is treated fairly and in accordance with the provisions of the Ordinance or the same as the input variables and output variables.

\section{References}

[1] Syah, Muhibbin, 2003. Psikologi Belajar. PTt. Raja Grafindo Persada, Jakarta

[2] Arifin, Dharma Surya, 2004. Manajemen Kinerja. Pustaka Pelajar, Yogyakarta

[3] Mulyasa, E. 2004, Implementasi Kurikulum 2004 Panduan Pembelajaran KBK. PT. Panji Rosdakarya, Bandung

[4] Sardiman,A.M., 2000. Interaksi dan Motivasi Belajar dan Mengajar. Rajawali Pers, Jakarta

[5] Darmadi, Pengembangan Model dan Metode Pembelajaran Dalam Dinamika Belajar Siswa (Online)

[6] Nazir, Mohammad, 2003. Metode Penelitian, Ghalia Indonesia. Jakarta

[7] Sarwono, Jonathan 2006, Metode Penelitian Kuantitatif dan Kualitatif. Graha Ilmu.Yogyakarta.

[8] Sutojo, T, Mulyanto, E., dan Suhartono,V., 2011, Kecerdasan Buatan, Andi Offset.Yogyakarta
About Author (s)

Merry Agustina

Univrsitas Bina Darma

Indonesia

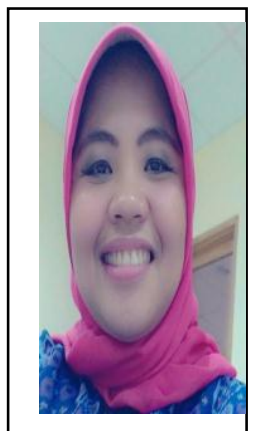

Merry Agustina, Author obtained a Bachelor degree of Computer Science (S.Kom), Department of Information System University of Bina Darma graduating in 1999. She earned a Master of Management in Information Systems Management concentration (MM) Graduate Program in the University of Bina Darma in 2006 and Master of Computer in Software Engineering Concentration (M.Kom) Graduate Program in the University of Bina Darma in 2011. Currently a Lecturer of Computer Science at Bina Darma University
Vivi Sahfitri

Universitas Bina Darma Indonesia

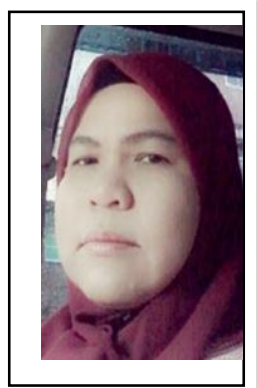

Vivi Sahfitri, Author obtained a Bachelor degree of Computer science (S.Kom), Department of Informatics University of Bina Darma graduating in 2001. She earned a Master of Management in Information Systems Management concentration (MM) Graduate Program in the University of Bina Darma in 2006. Currently a Lecturer of Computer Science at Bina Darma University. 